\title{
Mineralogy of Kimberley-type Pyroclastic Kimberlite and the Transition to Hypabyssal Kimberlite
}

\author{
Roger H. Mitchell ${ }^{1}$ and Barbara H. Scott Smith ${ }^{2}$ \\ ${ }^{I}$ Lakehead University, Thunder Bay, Canada, rmitchel@lakeheadu.ca \\ ${ }^{2}$ Scott-Smith Petrology Inc., North Vancouver, Canada, barbara@scottsmithpetrology.com
}

\section{Introduction}

Kimberley-type pyroclastic kimberlite (KPK; formerly tuffisitic kimberlite) is one of two classes of pyroclastic kimberlite. KPK is unique to kimberlites and distinctly different from the other class, Fort à la Corne-type pyroclastic kimberlite (FPK) which displays features comparable to subaerial basaltic pyroclastic rocks (Scott Smith et al. 2013). KPKs are best known as the diatreme-fill of many pipes in southern Africa. Optical and back-scattered electron petrographic data were obtained for a variety of KPK localities and the associated hypabyssal kimberlite (HK) to provide constraints on their emplacement. The KPK and the, as yet, not well-characterised HK-KPK transition zone in the 530545 Ma., Kennady Lake cluster, NWT, Canada are emphasised. These bodies exhibit features identical to KPKs occurring at the type locality in Kimberley, South Africa ( $\sim 90 \mathrm{Ma}$.; Mitchell et al. 2009), as well as other southern African mines ( 90 Ma. Orapa Botswana; 1100 Ma. Premier, South Africa; 90 Ma. Letseng, Lesotho) and the $\sim 230$ Ma. Pimento Bueno cluster, Brazil.

\section{Kennady Lake Kimberlite Cluster, NWT, Canada}

These kimberlites were emplaced into basement granitoids and are eroded bodies with diverse shapes that subcrop below surficial sediments and lakes. Tuzo (1.2ha.) is a typical vertical pipe (Hetman et al. 2004). In contrast, new data show that Faraday 2 and Kelvin are unconventional irregular-shaped inclined pipe-like bodies (Faraday 2: $20-40^{\circ}$ dip, $>400 \mathrm{~m}$ long, 20-90m wide; Kelvin: $12-20^{\circ}$ dip, $>700 \mathrm{~m}$ long, 30-200m wide, Fig. 1; Barnett et al., Nelson et al., Bezzola et al., this volume).

Tuzo, Gahcho Kuè Mine: The main pipe-fill kimberlite is dominated by typical KPK (Fig. 2a) in which the magmaclast selvages are composed of primary phlogopite, $\mathrm{Mg}$-amphibole, $\mathrm{Mg}$-Cr-spinel, apatite and $\mathrm{Nb}$-rutile. The intermagmaclast matrix consists of $\mathrm{Mg}$-rich $\mathrm{Ca}$-poor amphibole and $\mathrm{Al}-$ chlorite which differs from the serpentines and chlorites replacing the olivines. These new data confirm and enhance the results of Hetman et al. (2004) especially with regard to the presence of a continuous but inhomogeneous HK-HKt-KPKt-KPK textural transition with depth.

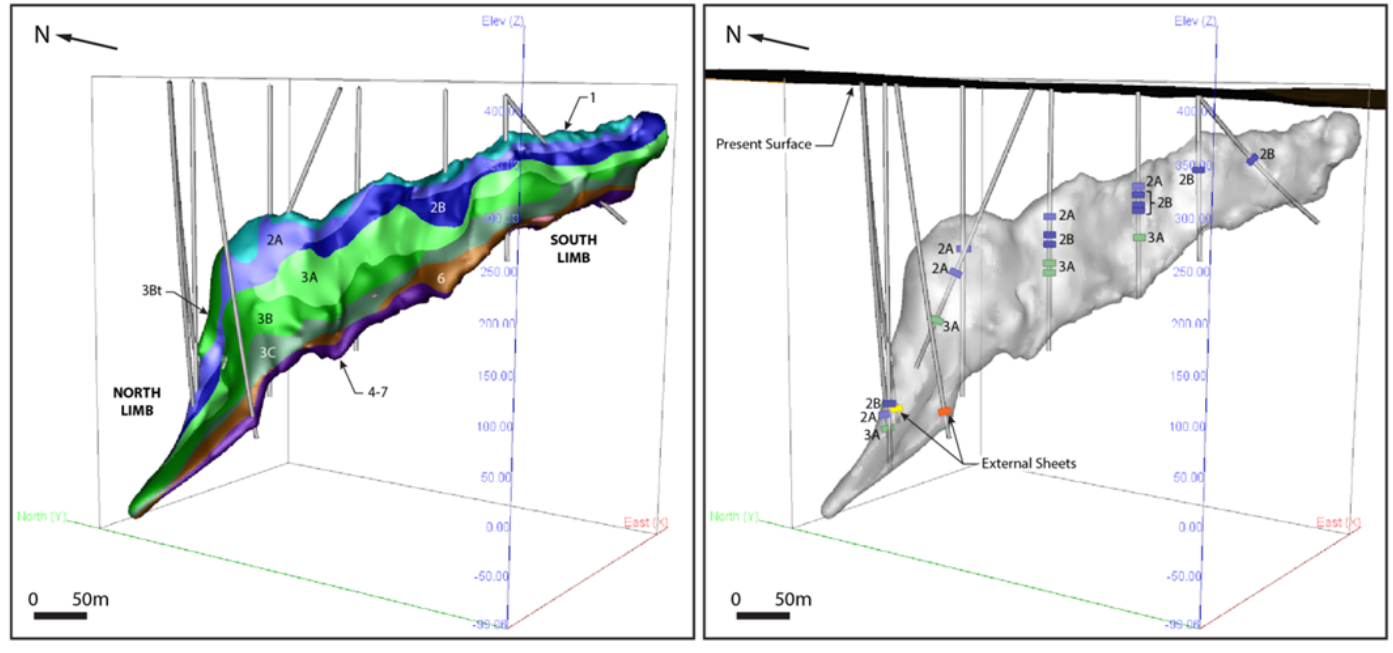

Figure 1: Oblique view of the Kelvin 3D geological model showing the investigated drillholes, and in (a) the "layer cake" internal geology $(2 \mathrm{~A}=\mathrm{KIMB} 2 \mathrm{~A}$ etc. $)$ and in (b) the sample locations. 

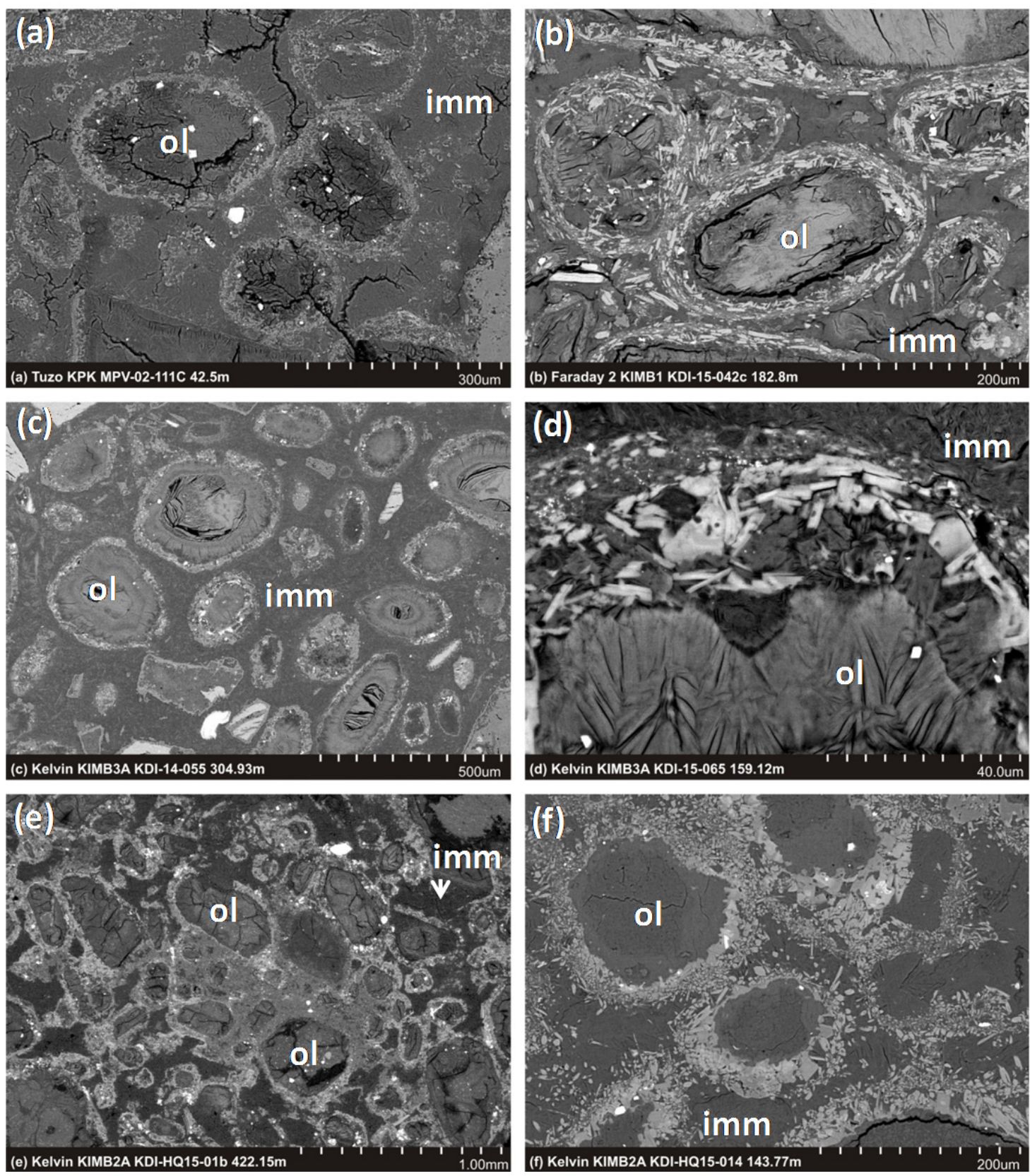

Figure 2: Back-scattered electron images of Tuzo, Faraday and Kelvin kimberlites. (a)-(d) are characteristic KPK: matrix-supported subspherical magmaclasts (formerly pelletal lapilli) with pseudomorphed olivine kernels (ol) and complete thin melt selvages composed of primary minerals including phlogopite and amphibole set in a different intermagmaclast matrix (imm). (e)-(d) illustrate HK-KPK transitional textures.

Faraday 2: The dominant kimberlite phase is KPK (Fig. 2b) with magmaclast selvages consisting of phlogopite, apatite and spinel set in a base of fibrous Mg-amphibole. The tangential orientation of the phlogopite laths confirms their formation is coeval with the magmaclasts. The occurrence of similar phlogopite in the intermagmaclast matrix indicates formation from the same magmatic crystallisation event. Deformation of juxtaposed magmaclasts suggests they were plastic at the time of solidification.

Kelvin: The three dominant and overall uniform juxtaposed phases of kimberlites (Fig. 1a) are each characterised by different textures. KIMB3 is typical KPK with increasing proportions of xenoliths and alteration from KIMB3A to KIMB3C. It is composed of matrix-supported discrete magmaclasts 
(Fig. 2c). The chlorites replacing the olivine within the magmaclasts are different in composition to the chlorite-smectite+/-amphibole of the intermagmaclast matrix (Figs. 2c,d). The unaltered groundmass amphibole and phlogopite in the magmaclast selvages (light coloured grains, Fig 2d) must have formed between the two or more separate chlorite events indicating sequential magmatic crystallisation and not external alteration. The adjacent KIMB2B is mainly $\mathrm{HK}$ to $\mathrm{HKt}$ in which most of the features are comparable to the external intrusive sheets except for the overall finer and more variable grain sizes as well as the development of diopside selvages on pseudomorphed olivines by assimilation of granitoid xenoliths. KIMB2A displays intermediate KPKt-HKt textures in which the incipient magmaclasts are not fully separate (Figs. 2e, f) and there are remnants of the original melt (central area enclosing both 'ol' in Fig 2e). Also, the grain size of the primary phlogopite/amphibole is intermediate between HK and KPK (Fig. 2f) suggesting more rapid crystallisation than HK.

\section{Conclusions}

The KPKs investigated all display similar features and are derived from three continents/cratons with emplacement ages ranging from 90 to 1100 Ma.. Thus, KPK is a texture that has been repeated in time and space. The development of different textures within the KPK-HK spectrum (Fig. 2) in juxtaposed phases of kimberlite at Kelvin (Fig. 1a) indicates that none of the textures result from pervasive postemplacement alteration in response to external non-kimberlitic fluids. The HK to KPK transition is characterised by increasing local country rock xenolith content, deuteric olivine replacement and magmaclast development. The fluidal magmaclasts form from the melt by the nucleation of primary minerals on olivine pseudomorphs. The unaltered amphibole and tangential phlogopite in the magmaclast selvages (Fig. 2b,d) must have formed between distinct magmatic chlorite-forming events, both primary and deuteric. The occurrence of the same primary minerals in the intermagmaclast matrix indicates it represents the end of a continuum of magmatic crystallisation involving increasingly rapid cooling. The occurrence of significant amounts of amphibole (cummingtonite/anthophylite with overgrowths of richterite) at Kennady Lake as opposed to diopside which is common elsewhere (e.g. Mitchell et al. 2009) reflects magma contamination resulting from the influx of granitoid xenoliths. The late-stage volatile-rich residual magmatic fluids cause extensive deuteric hydrothermal replacement of earlier-formed minerals by chlorite-smectite group minerals.

The occurrence of KPK-KPKt-HKt-HK textures in the essentially subsurface bodies at Kelvin (Fig. 1) and Faraday confirms that they did not form by deposition from subaerial pyroclastic eruption columns. This conclusion is supported by: (i) the absence of evidence for any such processes; and (ii) the similarity of pipe-fill HKs to intrusive sheets indicating they represent well crystallised subsurface magma (not welded pyroclastics). The degree of development of the KPK textures is different in each phase of kimberlite. Thus, the textures represent variable degrees of textural modification during the subsurface crystallisation of separate intrusive magmatic systems. The textures are also not uniform within each phase of kimberlite and the different transitional textures coexist on all scales. This indicates the transition is a dynamic process with profound changes in the liquidus and volatile phases over relatively small distances resulting from melt contamination, melt-fluid segregation and rapid sequential crystallisation processes.

\section{References}

Hetman CM, Scott Smith BH, Paul JL, Winter FW (2004) Geology of the Gahcho Kué kimberlite pipes, NWT, Canada: Root to diatreme magmatic transition zones. Proceedings of the $8^{\text {th }}$ International Kimberlite Conference. Lithos 76, 51-74.

Mitchell RH, Skinner EMW, Scott Smith BH (2009) Tuffisitic kimberlites from the Wesselton Mine, South Africa: Mineralogical characteristics relevant to their formation. Proceedings of the $9^{\text {th }}$ International Kimberlite Conference. Lithos 112 Supplement 1, 452-464.

Scott Smith BH, Nowicki TE, Russell JK, Webb KJ, Mitchell RH, Hetman CM, Harder M, Skinner EMW, Robey JV (2013) Kimberlite Terminology and Classification. Proceedings of the $10^{\text {th }}$ International Kimberlite Conference. Special Issue of the Journal of the Geological Society of India, Volume 2, 1-17. Springer India. 